\author{
(1) Hamza Aktaş, \\ - Derya Uçmak*, \\ (1) Zeynep Meltem \\ Akkurt*, \\ (1) Şahinan Karlı**
}

\section{Erythema Multiforme Developing Secondary to Orf Disease: Ten Cases}

\author{
Orf Hastalığına Sekonder Gelişen Eritema \\ Multiforme: On Olgu
}

\section{Abstract}

Turkey is a country which acquired a significant part of their income from farming and animal husbandry. Orf is a frequent disease all over the world, in areas where sheep and goat are raising. Complications due to orf are rare. Erythema multiforme is one of the complications of orf. A total of ten patients with lesions of erythema multiforme following orf were existed. Eight of the patients were female and two were male. All of the patients were living in rural areas and occupied with animal husbandry. The mean age of the patients was 34.3 years and ages of the patients ranged from 17 to 63 . The mean time for the formation of orf lesions was 11.4 (range 7-20) days, while the mean time passed for erythema multiforme development was 6.7 (range 5-9) days. In terms of orf position; in two of our patients there was localization on the left side whereas in the remaining patients, localization was found on the right side. Topical corticosteroids, systemic antibiotherapy and systemic corticosteroid therapy were planned to patients as a treatment. The results of this study show that orf-related erythema multiforme occurs more frequently than we thought. Patients referred to us with a complaint of erythema multiforme following orf infection. Awareness of the public and physicians will provide a better understanding of the relationship between orf and erythema multiforme.

Keywords: Erythema multiforme, ecthyma contagiosum, public health, parapoxvirus, orf, husbandry

\section{Öz}

Türkiye gelirinin önemli bir kısmını çiftçilik ve hayvancılıkla elde eden bir ülkedir. Orf, tüm dünyada, koyun ve keçi yetiştirilen yerlerde sık görülen bir hastalıktır. Orfa bağlı komplikasyonlar nadirdir. Eritema multiforme orfun komplikasyonlarından biridir.

Orfu takiben eritema multiformeleri olan toplam on hastamız mevcuttu. Hastaların sekizi kadın, ikisi erkek hastalardan oluşmaktaydı. Tüm hastalar kırsal kesimde yaşıyordu ve hayvancılıkla uğraşıyordu. Hastaların yaşları 17 ile 63 arasında değişmekle beraber ortalama yaşları 34,3'tü. Orf lezyonlarının oluşumunda ortalama süre 11,4 (7-20 gün) iken, eritema multiforme gelişimi için geçen süre ortalama 6,7 (ortalama 5-9) gündü. Orf lokalizasyonu açısından bakıldığında iki hastamızda sol tarafta yerleşim mevcutken geri kalan hastalarımızda sağ tarafta yerleşim mevcuttu. Tedavi olarak hastalara topikal steroid, sistemik antibiyotik tedavisi ve sistemik steroid tedavisi planlanmıştı.

Bu çalışmanın sonuçları göstermiştir ki; orfa bağlı eritema multiforme düşündüğümüzden daha sıktı. Bize başvuran hastalar orf enfeksiyonunu takiben ortaya çıkan eritema multiforme şikayetiyle başvurmuşlardı. Halkın ve hekimlerin bilinçlenmesi orf ve eritema multiforme ilişkisinin daha iyi anlaşımasını sağlayacaktır.

Anahtar kelimeler: Eritema multiforme, ektima kontagiozum, halk sağlığı, parapoxvirüs, orf, hayvancilik 


\section{Introduction}

Also known as ecthyma contagiosum or contagious pustular dermatitis, orf is a proliferative viral skin disease occurring in people who are in contact with sheep, goats and cattle that are infected (1). It is caused by parapoxviruses which are double-stranded DNA viruses belonging to the pox viridae family. The lesion may be solitary or multiple in the beginning and usually occurs on the arms, hands and face. After a 10-day-incubation period, it becomes a macular or papular lesion. It then turns into a nodule. Going through verrucous changes and becoming scabby, it heals in 4-6 weeks $(1,2)$. Complications related to orf occur rarely. Fever, lymphangitis, lymphadenopathy, secondary bacterial infections, papulopustular eruption and erythema multiforme (EM) can be listed among these complications $(3,4)$. EM is an acute mucocutaneous hypersensitivity reaction with varying degrees of blistering and ulceration. Common causes of EM are herpes simplex virus infection, mycoplasma infection, drug hypersensitivity, vaccination and drug-virus interaction (5). Although EM is a rare complication of orf, it was the main complaint that led our patients to the hospital. Here, we aimed at reviewing the demographic and clinical characteristics of patients who had lesions of EM complicating orf.

\section{Case Report}

Ten patients were identified. The mean age of the patients was 34,3 years and ages of the patients ranged from 17 to 63 . All the patients, expect for two, were female. All of the patients were living in rural areas and occupied with animal-raising. The mean time of onset of orf was 11,4 (range 7-20) days and the mean time passed from development of orf to EM was 6.7 (range 5-9) days. As to the location of orf, it involved the left side in two patients and the right side in the rest. EM lesions were of the minor type in all patients. EM lesions occurred within days. Lymphadenopathy was present in two patients. Treatment modalities included topical corticosteroids, systemic antibiotherapy and systemic corticosteroids. Systemic antibiotherapy was administered to the patients who had lymphadenopathy. Systemic corticosteroids had been initiated in only one patient. The demographic and clinical characteristics of the patients are reviewed in Table 1.

\section{Discussion}

Orf is a disease caused by parapoxvirus. Two types with different genetic characteristics are found in the nipple (pseudocowpox, paravaccinia virus or milker's nodule) and mouth (bovine papular stomatitis) of the infected animal $(3,4)$. Orf is a frequent disease all over the world, in areas where raising sheep and goats is common (3). Orf is transmitted upon contact with the infected animal or materials contaminated with the virus. Transmission between people has been reported only once $(3,6)$.

Farmers, shepherds, veterinarians and butchers constitute the occupational groups that are at risk. Furthermore, many cases have also been reported from Turkey after sacrificing animals in the religious feast of sacrifice (6). It is a macular lesion at the outset and turns into a papulonodular lesion with necrosis. It is a benign disease and heals itself in 4-6 weeks (2). Pyoderma, cat scratch disease, anthrax, tularemia, primary inoculation tuberculosis, atypical mycobacteria, syphilis chancre, sporotrichosis, keratoacanthoma and pyogenic granuloma are taken into consideration in the differential diagnosis $(3,4)$.

Clinical examination and history of contact will help diagnose orf. The final diagnosis is established by electron microscopy or

\section{Table 1. Demographical and clinical characteristics of patients with orf and erythema multiforme}

\begin{tabular}{|c|c|c|c|c|c|c|c|c|}
\hline Case & Age & Gender & $\begin{array}{l}\text { Animal } \\
\text { contact }\end{array}$ & $\begin{array}{l}\text { Orf time } \\
\text { of onset }\end{array}$ & Orf location (Figure no) & $\begin{array}{l}\text { EM time } \\
\text { of onset }\end{array}$ & LAP & Treatment \\
\hline 1 & 63 & $\mathrm{~F}$ & + & 15 days & $\begin{array}{l}\mathrm{R} \text { hand second finger } \\
\text { (Figure } 1 \text { ) }\end{array}$ & 7 days & - & $\mathrm{TC}+\mathrm{OA}$ \\
\hline 2 & 38 & $\mathrm{~F}$ & + & 7 days & $\begin{array}{l}\mathrm{R} \text { hand first finger (Figure } \\
2 \text { ) }\end{array}$ & $\begin{array}{l}5 \text { days } \\
\text { (Figure 3) }\end{array}$ & - & $\mathrm{SC}+\mathrm{OA}$ \\
\hline 3 & 17 & M & + & 10 days & $\begin{array}{l}\text { L hand second, third finger } \\
\text { (Figure } 4 \text { ) }\end{array}$ & 7 days & + & $\mathrm{SA}+\mathrm{TC}$ \\
\hline 4 & 23 & $\mathrm{~F}$ & + & 20 days & $\mathrm{L}$ forearm & 7 days & - & TC \\
\hline 5 & 40 & $\mathrm{~F}$ & + & 15 days & $\mathrm{R}$ hand first finger (Figure 5) & 7 days & + & $\mathrm{SA}+\mathrm{TC}+\mathrm{OA}$ \\
\hline 6 & 29 & M & + & 10 days & $\begin{array}{l}\mathrm{R} \text { hand third finger } \\
\text { (Figure 6) }\end{array}$ & 7 days & - & TC \\
\hline 7 & 28 & $\mathrm{~F}$ & + & 10 days & $\mathrm{R}$ hand second finger & 7 days & - & $\mathrm{TC}+\mathrm{OA}$ \\
\hline 8 & 31 & $\mathrm{~F}$ & + & 10 days & $\begin{array}{l}\mathrm{R} \text { hand dorsum, fifth finger } \\
\text { (Figure 7) }\end{array}$ & 5 days & - & $\mathrm{SC}+\mathrm{TC}$ \\
\hline 9 & 24 & $\mathrm{~F}$ & + & 10 days & $\mathrm{R}$ hand dorsum & 9 days & - & $\mathrm{TC}+\mathrm{OA}$ \\
\hline 10 & 50 & $\mathrm{~F}$ & + & 7 days & $\mathrm{R}$ second finger & 6 days & - & TC \\
\hline
\end{tabular}




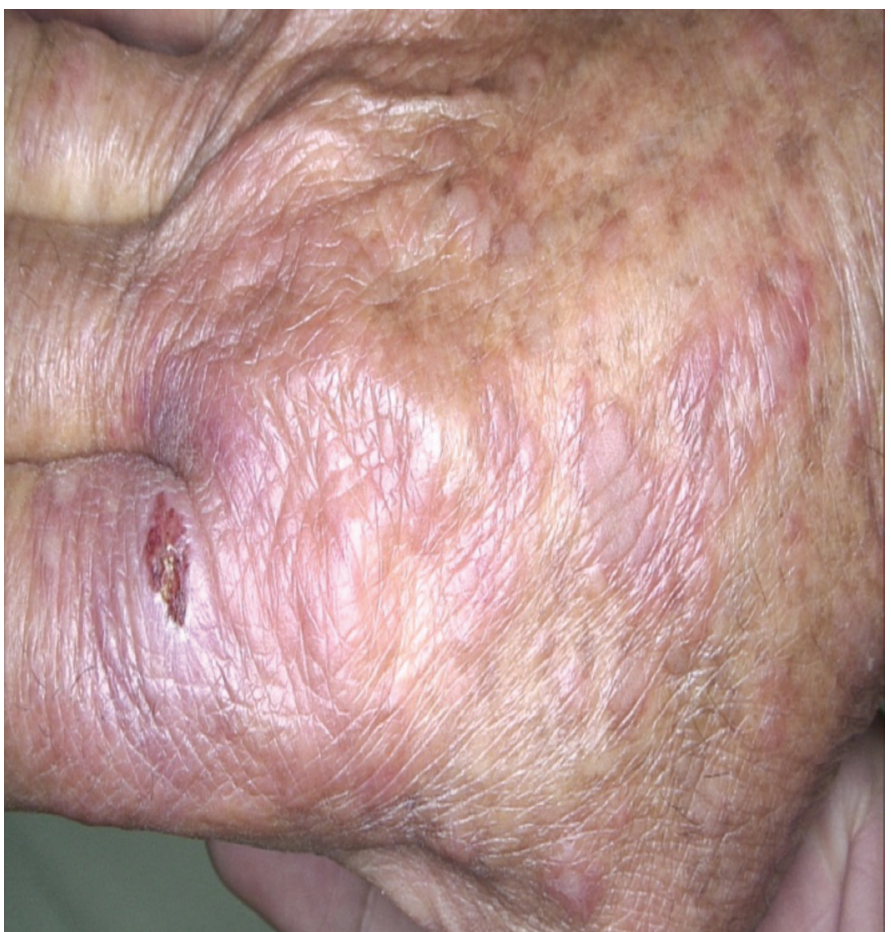

Figure 1. Linear erosion and livid plaque on the second finger

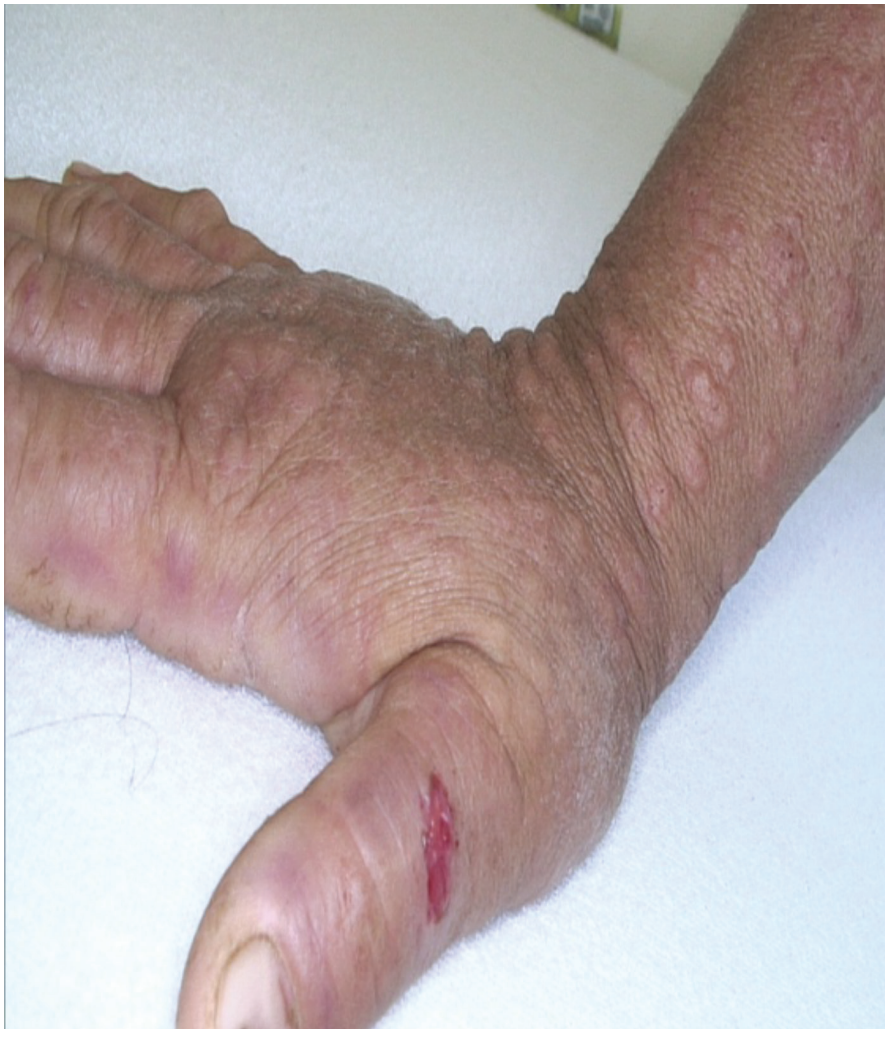

Figure 2. Linear erosion on the thumb

through isolation of the virus. Histopathological examination will reveal cells with vacuoles which contain intracytoplasmic inclusion bodies in the epidermis $(2,3)$. As orf itself was not the cause of presentation to the hospital, our patients did not

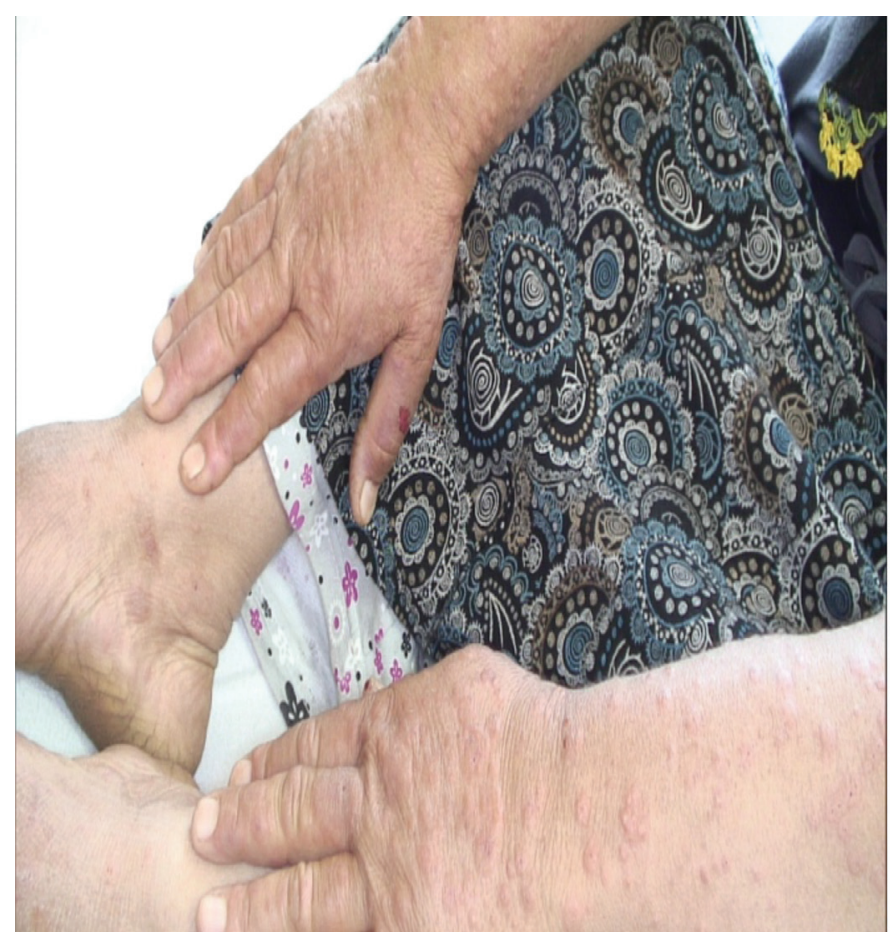

Figure 3. Erythema multiforme lesions on the hand dorsum and forearm

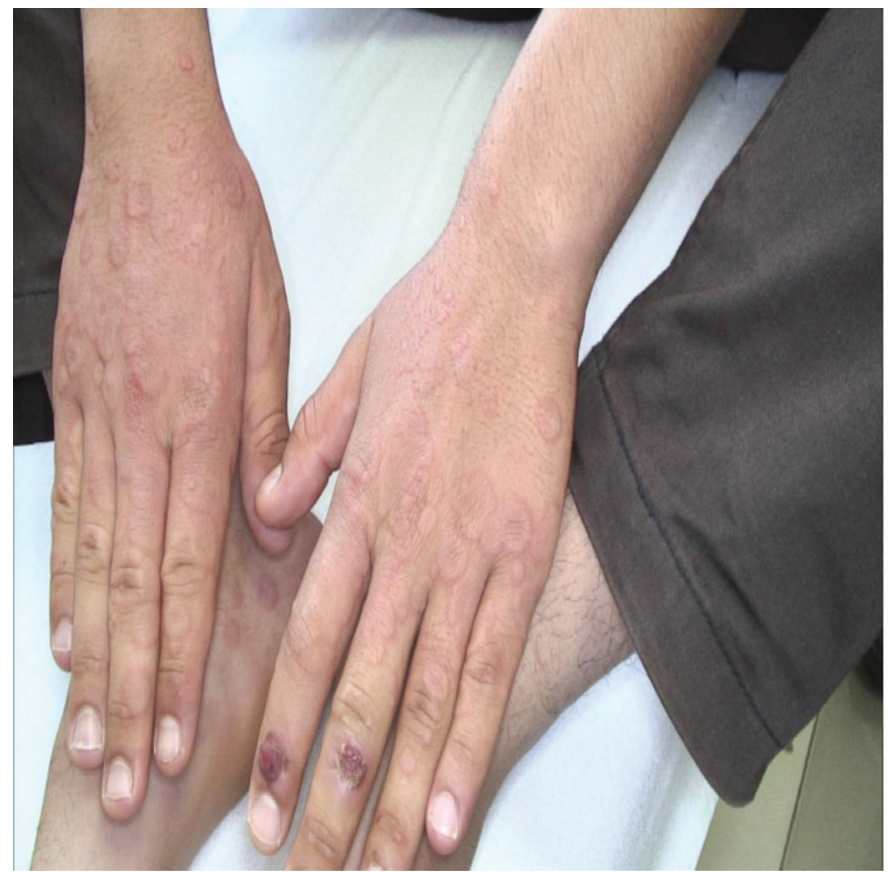

Figure 4. Crusted papular lesion on the left hand second and the third finger

consent to histopathological procedures. Such complications as secondary bacterial infections, lymphadenopathy, lymphangitis, papulopustular eruption and EM may occur in this group of patients. Among patients with EM, 4-13\% were diagnosed with orf $(6,7)$. However, the exact rate of EM as a complication of orf is not known $(6,8)$. In our patients, EM occurred in 5-9 days after onset of orf. A common feature of 


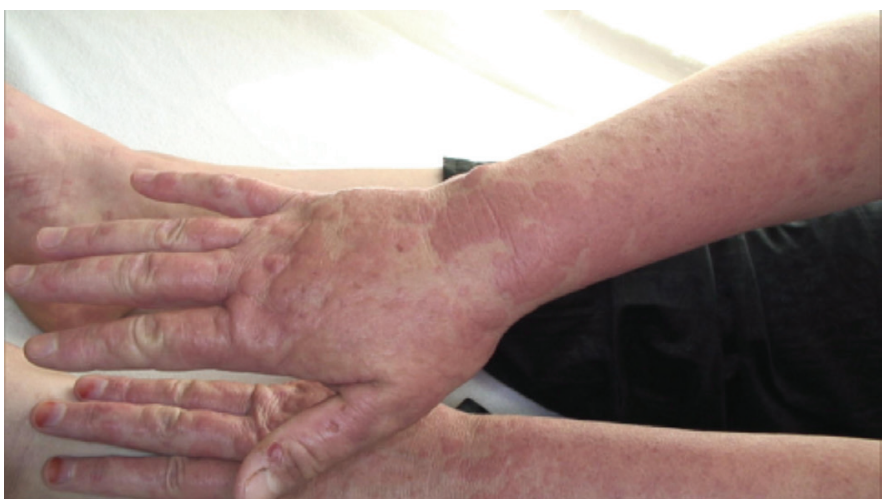

Figure 5. Erosion on the thumb of the right hand and targetoid lesions

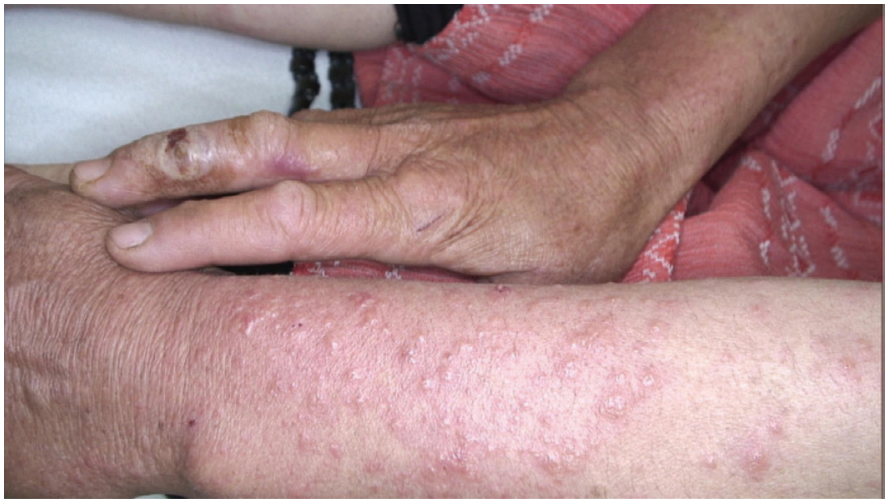

Figure 6. Crusted papular lesion on the third finger of right hand and targetoid lesions on the left arm

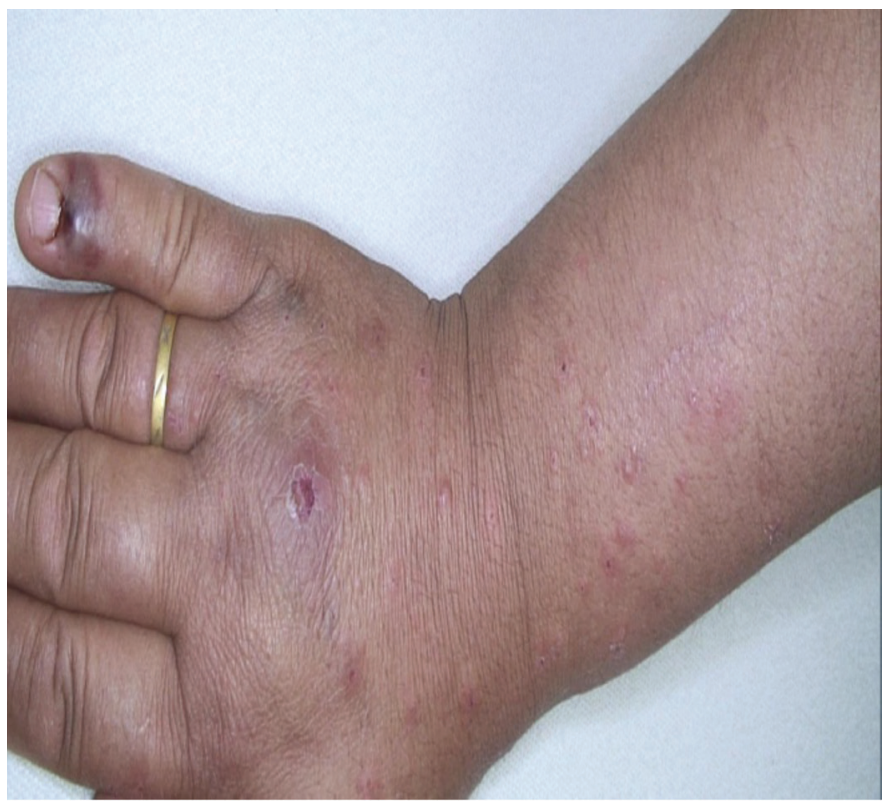

Figure 7. Nodular lesion on the fifth finger of the right hand

our patients was the fact that all of them presented to the outpatient clinic in panic with complaints of EM lesions, and history of the patients and clinical examination revealed the existence of previous orf lesions in all of them.
Even though orf lesions are usually found as solitary lesions on the hands and fingers, they have rarely been reported on the face, nostrils, tongue, eye lids and perianal region. In addition, orf can introduce as an atypical lesion or multiple lesions (9).

Although lesions of orf are usually easily recognized and heal spontaneously, sometimes orf may present with atypical involvement of the face and this may cause difficulties in diagnosis.

Unnecessary testing and surgical interventions are carried out in such cases. To prevent this, orf should be kept in mind in areas where animal-raising is common $(9,10)$.

There is no specific treatment for orf. Treatment should be tailored according to the complication. Wound cleansing should be paid special attention in order to avoid secondary bacterial infection. Local iodine application may be helpful. In case of infections, proper antibiotics can be used. Advanced cases can be managed by electrocautery, cryotherapy and surgical excision $(11,12)$.

As orf is a self-limited disease, early diagnosis is important in avoiding unnecessary treatment and alleviating stress felt by the patients. Clinical history assumes considerable importance in the diagnosis (12).

Orf, which appears quite frequently in our region, was not a cause of presentation to the hospital for our patients unless it brought along significant pain and infection. Instead, it was EM, a rare complication of orf that made our patients concerned and led them to see a physician. Orf-related EM occured more frequently than we thought. Therefore, awareness should be raised in people who are involved in animal husbandry as well as physicians who deal with community health. In conclusion, a detailed dermatological examination and a good history may lead physicians to consider orf in patients of rural areas who present with EM lesions. This way, unnecessary tests and treatments as well as referral of the patient to a more advanced centre may be avoided.

\section{Ethics}

Informed Consent: It wasn't taken because this study is retrospective.

Peer-review: Externally and internally peer-reviewed.

\section{Authorship Contributions}

Surgical and Medical Practices: H.A., Ş.K., Concept: D.U., Z.M.A., Design: D.U., Z.M.A., Data Collection or Processing: H.A., S..K., Analysis or Interpretation: D.U., H.A., Literature Search: D.U., Writing: D.U., H.A.

Conflict of Interest: No conflict of interest was declared by the authors.

Financial Disclosure: The authors declared that this study received no financial support.

\section{References}

1. Lo C, Mathisen G. Human orf in Los Angeles County. West J Med 1996;164: 77-8. 
2. Ünal G, Gündeş S, Üstüntürk M. Human orf: echtyma contagiosum report of five cases. Turk J Med Sci 2002;32:173-5.

3. Snyder RR, Diven DG. Orf (Contagious pustular dermatitis, contagious ecthyma). In: Freedberg IM, Eisen AZ, Wolff K, et al, editors. Dermatology in General Medicine. 6th ed. New York: McGraw-Hill Inc.;2003. p. 2110-14.

4. Diven DG. An overview of poxviruses. J Am Acad Dermatol 2001; 44:1-16.

5. Koley S, Sarkar J, Choudhary S, et al. Erythema multiforme following application of hair dye. Indian J Dermatol 2012;57:230-2.

6. Schmidt E, Weissbrich B, Bröcker EB, et al. Orf followed by erythema multiforme. J Eur Acad Dermatol Venereol 2006;20:612-3.

7. Johannessen JV, Krogh HK, Solberg I, et al. Human orf. J Cutan Pathol 1975; 2:265-83.
8. Assier H, Bastuji-Garin S, Revuz J, et al. Erythema multiforme with mucous membrane involvement and Stevens-Johnson syndrome are clinically different disorders with distinct causes. Arch Dermatol 1995;131: 539-43.

9. Turan E, Yurt N, Erdemir AT, ve ark. Fasiyal Orf. Turk J Dermatol 2012;6:58-60.

10. Gurel MS, Ozardali I, Bitiren M. Facial orf. Turkiye Klinikleri J Med Sci 2003;23:412-5.

11. Degraeve C, De Coninck A, Senneseael J, et al. Recurrent contagious ecthyma (Orf) in an immunocompromised host successfully treated with cryotherapy. Dermatology 1999;198:162-3.

12. Turan E, Yesilova Y, Ucmak D. A case of orf (ecthyma contagiosum) with multiple lesions. J Pak Med Assoc 2013;63:786-7. 